\title{
The 97 theses (04-05 September 1517): A precursor to the 95 theses (31 October 1517)?
}

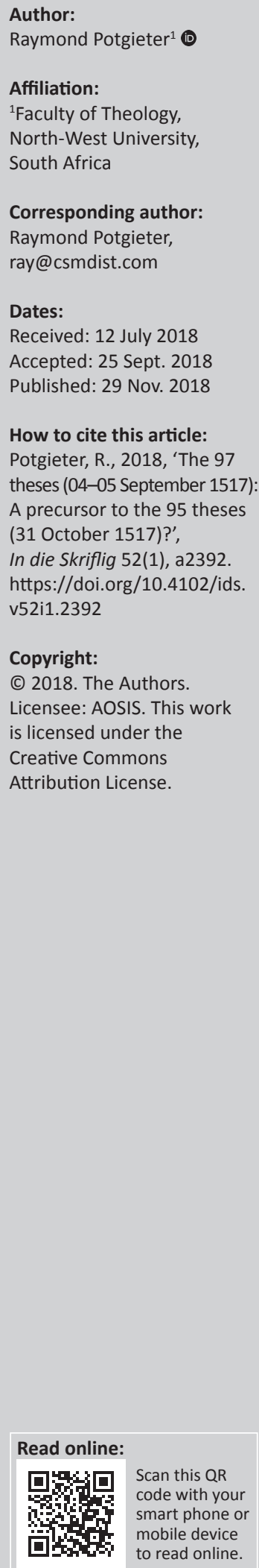

\begin{abstract}
While Martin Luther's 95 theses engage theologians worldwide, little is made of the 97 theses. It is not often mentioned that these theses had appeared for an academic debate just a month before the 95 theses. A reason for this is that some scholars suggest that the 97 theses reflect a more scholastic approach to theology. This is no doubt true. However, the scholarly content of these theses reveal the challenges that Luther directed at certain Romish doctrines and practices of the day, challenging scholastic methodology. Scholars often engaged students and sometimes invited public participation to reflect and debate formulated theses. It is suggested that the content of the 97 theses served to stimulate Luther into formulating the more famous 95 theses. This article will reflect on the scholastic practice of formulating theses for the purposes of debate and give an overview of the theological content of the 97 theses. Another more comparative, study could pinpoint the more specific entrance of these theses into the formulation of the 95 theses.
\end{abstract}

\section{Introduction}

The Christian church celebrated the 500th anniversary of the Reformation, sparked by the nailing of 95 theses $^{1}$ to the church door of Wittenberg on 31 October 1517. Little is, however, made of the 97 theses posted in September 1517 by Martin Luther to invite debate. ${ }^{2}$ The earlier document is rarely mentioned in connection with the former, and consequently subjected even less to rigorous scrutiny. The reason may be that the 95 theses and the story of Luther's reaction and the responses of the Church of Rome as well as the wider European community, are so well known that it has become the primary context and dominates the narrative for the origin of the Reformation. For that reason the 97 theses is revisited in this study.

The Disputatio contra scholasticam theologiam was initially written for students and fellow academics to invite their responses in debate. By 1517, Martin Luther's rigorous engagement with the Word of God led to a refinement of his theological understanding of the Bible, in particular of the Pauline theology. Framing theses was nothing new. Andreas Bodenstein framed 152 theses in Wittenberg by 26 April 1517 which showed his support to his colleague, Martin Luther, within the biblical humanist school of thought at the time (Junghaus 2004:25).

There is little doubt in my mind that the 95 theses, which appeared on 31 October 1517, had the 97 theses, albeit somewhat covertly, underlying them. A clearer understanding of these 97 theses comes, among others, ${ }^{3}$ when taking into account that Luther was already advocating engagement with original sources. ${ }^{4}$ A focused attention on biblical and patristic literature (and in that order) brought about a determined shift. Scholastic theology was challenged in its occupation of its hitherto dominant position for determining theological interpretation and the agenda of matters. To appreciate the significance of this move by Luther, one has to bear in mind that this was precisely the context in which he had been nurtured theologically and philosophically.

To that end, this article will illustrate the accepted protocols that invite academic debate through the presentation of formulated theses. Then the 97 theses will be dealt with in general fashion, showing how Luther began to advocate the initial shift from ecclesial authority to engagement

\footnotetext{
1.Theses are summarising salient points of some academic subject for scholarly debate. More recent theses are, for instance Karl Marx's 11 theses (1976:61-65) of Ludwig Feuerbach, or more to the point in theology, Friessen's 95 theses (2009) on Herman Dooyeweerd which have served more recently as reflective commentary, stimulating conversation.

2.Ryan Reeves (2015) has no hesitation in suggesting that these theses were nailed to the same church door in Wittenberg - the usua scholarly practice that invite debate.

3.There is, of course, the wider context of Luther's personal experiences in wrestling with sin, his monastic environment, the influence of his Augustinian order, allegiances to the Pope and the Catholic Church, and so on.
}

4.A shift from Medieval syllogistic methodology. 
with biblical and patristic literature. In conclusion, it will be suggested that further research on the influence of the 97 theses on the 95 theses $^{5}$ and other writings may prove to establish the maturing of Luther's theological development.

\section{Scholasticism and the practice of inviting debate}

\section{Sketching the scholastic milieu of the Middle Ages}

The purpose of this brief sketch of scholasticism is to give some background to the milieu in which Martin Luther and other theologians of the High Middle Ages found themselves. In that light, this is then not another brief summary of the well-documented history of scholasticism.

Garcia (1994:1) summarises the pursuit of scholarly thought from an Aristotelian perspective as the identification of causes and principles'. These inherited rational Aristotelian premises engaged and challenged the Scholastics from Aquinas onward. Some of the most prominent Scholastics, addressed in the 97 theses, were the following: Peter Lombard (1100-1160), Bernard of Clairvaux (1090-1153), William of Ockham (ca. 1280-1349), John Duns Scotus $(1308)^{6}$, Cardinal of Cambrai, Pierre d'Ailly (1350-1420), Gabriel Biel $(1410 / 1425 ?-1495)^{7}$. Luther also refers to Aristotle (384-322 BC) and Porphyry (c. 233/234-c. 303/304). There is little doubt that Luther was conversant with these and other scholastic writings. For instance, from this rational point of view, human nature and individuality are to be understood from causes, principles and elements which determine them. If this is accepted, the problem of individuation or the unique differentiation of one thing from another, sharing the same set of causes and principles, must be viewed in terms of some form of determination. In short, these premises did not quite fit into a classic understanding of theology.

It was Aquinas who famously introduced Aristotle into Christian theology. To fuse the two different thought systems of Aristotle and Christianity, he introduced a dualism of grace and matter (Potgieter 1994). Aquinas masterfully synthesised the two on the premise that all truth is derived from God. ${ }^{8}$ He develops this premise to conclude that reasoned philosophy or science derives truth from reason and that theology derives its truth from revelation. In that way, each domain, in following the determinist law of logic, retains its sovereignty, but derives its ultimate authority from 5.Many hold to the view that there is a crisis for theology in that it struggles to be
recognised as a scientific discipline: Within the last fifty years alone, the concept of
reason has changed materially at least twice, first in the wake of Critical Rationalism
and the Frankfurt School after 1968, and then in light of the New Age movement,
beginning in the 1990 s (Barth 2013:400) beginning in the 1990s (Barth 2013:400).

6. Referred to as the 'Cardinal' without mentioning his name in the 97 theses.

7.Van 't Spijker (2001) reflects on Luther's rejection of scholastic scholars. He contrasts this to the development of opposite theological sides (Luther/Zwingli) as the consequence of differing theological interpretations in the Reformation.

8.Luther, of course, never quite broke away from Aristotelian influence evident in his soteriology, for example concerning the 'substantive et essentialiter' based on the Aristotelian concept of substance which influenced his understanding of the eucharist (Barth 2013:263).
God as the author of truth. As scholastic insights developed these premises, they gradually but consistently no longer found a suitable fit in a classic understanding of patristic and Augustinian theology.

As long as this distinct dualism ${ }^{9}$ lasted, scholasticism lasted (Romanoski 2016:318). It was a case of refining and developing Aristotelian thinking through early dialecticism from which scholasticism emerged. 'Scholasticism consists in the conviction that reason is to be used in the elucidation of spiritual truth and in defense of the dogmas of the Faith' (Romanoski 2016:318).

What must also be borne in mind is that the wider context of the intellectual milieu of the High Middle Ages would, among others, include a continual engagement with Aristotle's works. Written in Greek, the Scholastics had to grapple with that language in attempts to express complex words and phrases into forms and meanings for a Latinised employment in philosophy and theology. The list could be expanded, but this suffices to demonstrate some of the complexities that scholars during the Middle Ages had to deal with that deeply influenced and challenged budding theological scholars such as Martin Luther and which bore testimony to his scholarship and theological training.

\section{The practice of theological quodlibeta, statements, propositions, or theses}

During the Middle Ages, when a scholar had gained some reputation, a debate would most likely ensue regarding questions de quodlibet [about anything] submitted by persons for debate. These quodlibeta ${ }^{10}$ originated from all classes of persons and from the widest reaches of Christendom (Romanoski 2016:320). Alternately, they would be raised by members of the audience at a disputation. These quodlibeta would then be dealt with in what was commonly known as a disputation or determination (Romanoski 2016:320). Theological topical quodlibeta abounded and formulated disputations were more likely to be seasonal in that they would most likely occur before Christmas and Easter such as at the University of Paris (ca. 1230-1330) (cf. Schabel 2007). ${ }^{11}$ The manner of treatment of the quodlibet was generally in the form of a thesis or a formulated objection and proposed solution (Romanoski 2016:320). Yet, presenting arguments for debate could be risky at times as John Reuchlin ${ }^{12}$ in Cologne found. Luther's fellow Augustinian, George Spalatin, asked Luther for his opinion regarding accusations

9.The Scholastics were quite content with dualism (distinguo), while Luther's personal experience struggling with sin, conscience, et cetera led to developing a sharply distinguished dialectical approach (Barth 2013:471)

10.'[W]hatever you wish/whatever pleases' would be acceptable translations for a disputational context.

11.Schabel (2007), in this volume, covers examples of the quodlibeta. The topics range from examples of the Dominican, Carmelite, Augustinian, continental Fransciscan
orders as well as those at Oxford University and includes the involvement of a number of individuals such as John Duns Scotus, John of Pouilly and others. My own use of the term is in the sense of being topical, while the disputations or theses tease out the topic more specifically.

12.It was Reuchlin's De rudimentis hebraicis that accompanied Luther on his return to Wittenberg from Erfurt - a clear indication of his engagement with the original languages of the Bible by 1511 (Junghaus 2004:25). 
against Reuchlin about blasphemy and Jews (Smith 1911: 29-30). To this Luther replied, 'He is only proposing questions for debate, not laying down articles of faith, which alone, in my opinion, absolves him.'

Nailing statements, propositions, these ${ }^{13}$ or disputations in a public place was done so that the matters raised could serve as substance for conversation. In other words, this was therefore not a novel practice of Luther ${ }^{14}$. While the 95 theses were topically in the style of theological quodlibeta, the 97 disputations or these ${ }^{15}$ seem to have had a different audience in mind. It is probably for that reason Luther included the word disputation in the title Disputatio contra scholasticam theologiam [Disputation against scholastic theology]. ${ }^{16}$

By 1517, Martin Luther had come a long way in his wrestling with theological matters. ${ }^{17}$ As a novice he had engaged with scholastic theology, but tended to read the Scriptures for existential meditation unlike the intellectual approach of the reigning scholastic influence (Beutel 2004:5). His theological studies served to continually refine his understanding of biblical and patristic theologies. After his studies through Psalms, Luther (1863) concluded that it eulogised God. Then Luther discovered the essence of the gospel while lecturing through Romans, and in particular, it was the phrase the righteousness of God in Romans 1:17 which arrested him. So engaging did his lectures become that his students began promoting the study of Paul among other faculty members. Thus, it began a gradual reforming of the Wittenberg faculty and students, not least because the New Testament in Greek by Desiderius Erasmus was available by 1516. For Luther, Paul ${ }^{18}$ was an apostle of Jesus because of what he preached and taught to both the Jew and Gentile.

During 1514 to 1517, Luther completed his lectures on Romans. He then proceeded to study and lecture on Galatians and Hebrews. ${ }^{19}$ It was this latter book that clarified his newly discovered Pauline theology. This led to greater clarity in his studies of the Psalms, and in particular,

13.These terms are basically interchangeable, but a preferred term would sometimes be determined by the purposeful context of engagement. One modern example will suffice. Lull (2004:43) has no hesitation to interchange the word theses with disputations.

14.As with many other reformers, Luther had no hesitation to commit his thoughts to print - a secret of the reformers' success (Hillerbrand 1968: preface).

15.For the sake of consistency, I will now refer to the 'disputation and disputations' as 'thesis and theses'.

16.I will use the abbreviation ' $D$ ' followed by the disputation number(s) when I refer to the 97 disputations or theses from the 'Disputation against Scholastic theology' (1517) (Luther in Lull 2012:3-13).

17.Such was the measure of his later stature that one could speak about 'fear of Luther', which nowadays would probably translate into 'a fear about Luther' suggestive of embarrassment (Barth 2013:4)

18.Luther was convinced that Paul's writings and 1 Peter surpassed the synoptics, because: the books show you Christ and teach you all that is necessary and salvatory for you to know, even if you were never to see or hear any other book or doctrine (Hillerbrand 1968:41-42).

19. Medieval scholasticism shaped Luther's mindset. He lectured on Genesis (1513) Psalms (1513-1515), Romans (1515-1516), Galatians (1516-1517), Hebrews (1517-1518), and revisited Psalms again (1518-1521) (Thiselton 2015:563). But what is to be takn note of is that even in 1517 Luther's lectures on Hebrews reflected a medieval form and style, but in content they proclaim the sacrifice of Christ and the power of God's Word' (Thiselton 2015:564). Luther did not entirely dismiss Scholasticism.
Augustine's understanding of the continuing narrative or testamentum fidei of the Old and New Testaments (Hagen 1974:31-54).

One of the dynamics that I think may be discerned during this period of lecturing on Pauline texts is the metaphor of engaging in conversation. There were apparently two conversations in which Luther was engaged. Influenced by the Augustinian order that he belonged to, he consistently compared Augustine's theology with that of his findings from Pauline texts ${ }^{20}$ in the Bible. Such a conversation saw Luther subjecting personal quodlibet after quodlibet to the scrutiny of Pauline theology and to that of the Bible. Again and again he found answers echoed in Augustine and conclusively so in Pauline texts. From these emerged his formulation of the disputations or theses. His own comprehension may have suffered due to differing degrees of clarity and lack of biblical consistency, but Luther was all the while making progress in theological clarity, and in so doing, increasingly found himself outside the confines of scholasticism.

For that reason, I suggest that what emerged from Luther was a second set of scholastic quodlibeta - one that could only be adequately addressed by returning to the church's original sources. This would have been a consequence which naturally occurred, as he derived insights from truths immediately available from the Bible and the patristics. In time this led to questioning the scholastic formulated theological premises of the day. This eventually took shape in the form of the 97 disputations or theses. What is at stake here is the establishing of an adequate starting point for theological judgement, a theology that does not start with reliance on human moral integrity, later crystallised as theologia gloriae, ${ }^{21}$ but on Christian staurology succinctly expressed as theologia crucis (McGrath 1990).

\section{The 97 theses: Disputations against scholastic theology, 1517}

It seems that Luther adopted the scholastic practice of the day to formulate a disputation or thesis and to submit it to his student(s) who would then be required to analyse, question and defend it which is a good academic exercise, except in the following case: 'Luther started his attack on the theology of Gabriel Biel, thereby attacking scholastic theology as such' (Van 't Spijker 2001:295). Among others, he rejected a methodology founded on Aristotelian ethics and a theology reliant on its accompanying Aristotelian insights. Rather, Christian confession was a matter of belief and not of knowledge and logic (Van 't Spijker 2001:295).

It was common practice to sometimes compile the results of these debates and to formulate a new thesis based on the

20.Reminiscent of Johann von Staupitz's naming of Paul as the tuba evangelii [trumpet of the gospel].

21.Developed in the criticisms which appeared some months later, as contained in the Heidelberg Disputation of April 1518, famously phrased in Thesis 20 'Ergo in Christo crucifix est vera Theologia et cognito Dei' (Van't Spijker 2001:295; cf. Luther in Lull 2012:4 D. 20). The actual disputation took place on 26 April 1518. 
additional knowledge so as to present them anew to students. While this cannot be indisputably claimed for the 97 disputations against scholastic theology, it is worth taking the aforementioned into consideration, as it is highly unlikely that these thoughtfully framed disputations or theses were formulated in a hurry.

Loeschen (1976:20ff.) claims that, relationally for Luther, the 'theology of reason without the Word of God ... does not get to the root of human $\sin ^{\prime}$ or any other theological subject for that matter. In fact it leads to 'an overestimation of man's ability'.

These disputations against scholastic theology are adequately translated and reprinted in Lull (2004:3-7).

\section{A brief overview analysis of the 97 disputations or theses}

As a theological movement, scholasticism dominated the Catholic Church since the 13th century (Van 't Spijker 2001:291). The 97 theses were critical of scholasticism as a whole on the one hand, but on the other hand, there is no evident prolegomena to accompany Luther's understanding of theology. This is evident in the two scholastic streams of the Thomistic via antiqua and the via moderna approaches of Duns Scotus (Luther in Lull 2012:3 D. 6) and William of Ockham $^{22}$ (Luther in Lull 2012:6 D. 56). This is immediately evident in reading 'contra Gabrielem/Scotum'Scholasticus' ${ }^{23}$ which is in keeping with 'the style of disputation then in use; saying precisely against whom one was speaking' (Barth 2013:401). Both these streams were evident in the scholastic dealings with Augustinian theology, but reflected Aristotle's influence. The discovery of the press (1450s) was before the Reformation and its publications soon made these opinions and early humanism publications widely accessible (Barth 2013:11, 399).

The 97 theses featured before the evident split between humanism and the Reformation (cf. Van 't Spijker 2001:290). At the same time, something must also be said about what later became the brand name for Luther's theology (Barth 2013:77) in dealing with scholastic methodology. While the term theologia gloriae came to represent much of scholastic theology, it allowed Luther to develop his later theology. Loeschen (1976:43) suggests that this led to his explicit dialectic tensions between coram deo [righteousness in the eyes of God] and coram mundi [righteousness in the eyes of the world]. Barth (2013:77-99), on the other hand, seems predisposed to the idea of displacement in which theologia crucis displaced theologia gloriae. Not that Luther denied the usefulness of coram deo, but in the matter of claiming to

22. Ockham who denied "the existence of "causality" as a phenomenon outside of the human mind' was one of the schoolmen who most influenced Luther (Thiselton 2015)

23. Luther again felt the need to address the scholastics, especially Biel and d'Ailli by 1539 and the errors of the Sorbonne 'the mother of errors' (Barth 2013:403). Bie was the great interpreter of Ockhamistic tradition at the time. One of the reasons was the resurgence of scholastic methodology in the 1530s (Van 't Spijker 2001:291) present the fullness of truth, it was found inadequate ${ }^{24}$ and so the emphasis is not just on opposite dialectic tensions, but on supersession.

What now follows, must be seen in the light of the above contextual sketch. For that reason, I will refrain from repeating the obvious and concentrate on Luther's 97 theses. This will be done in thematic style rather than with a focused concentration on individual theses. What should emerge is a broad overview of Luther's line of thought in presenting these theses which highlight some of the salient arguments employed. There is, for instance the question of the validity and authenticity of the scholastic way of claiming ecclesial authority which Luther contrasts with patristic authority derived from Scripture. Scholastics placed an inordinate trust in human reason and free will, using scholastic methodology to elucidate Christian theology. Instead of clarifying scriptural positions on matters in debate and publication, Luther claimed that Aristotelian syllogistic influence ${ }^{25}$ leads to synthesising the obscure of what ought to be made clear to reflect Luther's own experience through his studying, preaching and lecturing on Pauline texts.

What follows in analysis will be an overview of a suggestive outline of Luther's contentions. One could easily trace Luther's seminal thoughts regarding the human will, depravity of man, grace, sovereignty of God and more themes that he developed more clearly as he matured in his theological discoveries and subsequent knowledge. My intention is to cover the 97 theses in a broad sweep. Not much is published in this regard, probably because the first impression is that these theses pertain to scholasticism exclusively. What is, however, in my opinion, overlooked, is the obvious theological clarity that glimmers and is implied in these formulated theses. Some of Luther's future theological formulations on particular themes such as grace, righteousness, depravity and more are intertwined in these theses, but presented here in seminal form. From time to time some emphasis will highlight one or more of these themes, but it will be contextual rather than an exclusive study. For the sake of brevity, this article will not trace particular themes beyond the 97 theses. That is a study for another day.

\section{A proposed outline of 'Disputation against scholastic theology'}

\section{Establishing a sound theological baseline (disputations or theses 1-3)}

Augustinian Luther (Luther in Lull 2012:3 D. 1,3) is adamant in defending the patron of his order and the patristics by resorting to questioning scholasticism and its methodology. The reason is obvious: through continued scholastic

24.These dialectics or displacements were developed more fully in, for instance The Freedom of a Christian (1520) and The Bondage of the Will (Luther 1525; see Barth 2013:77-99 for a recent scholarly approach to this matter). Relating this principle of displacement to the modern context, Barth (2013:83) suggests its emergence when extremist ideologies such as Marxism or Islam make their appearance.

25.Medieval syllogism traces its roots to Aristotle and is based on deductive reasoning that a conclusion based on two or more propositions, true or assumed to be, may be accepted to be true or assumed to be so. Logicians generally based these propositions on available texts on available sources for this method. 
syntheses, theological shifts occurred away from patristic, and in particular, Augustinian theology which led into scholastic obscurantism. Although scholastic arguments and reason tended to satisfy its advocates, this also allowed the revisiting of the exaggerated views of Pelagianism and Manicheanism (Luther in Lull 2012:3, 4 D. 2, 8) ${ }^{26}$ through modifying the strong arguments used by Augustine. For that reason, the will of man is seen to act as a decisive factor in theology. Although discounted by the Early Church fathers and especially Augustine, this once again came under the loupe of scholastic reasoning. Consequently Augustine was seen as excessive in his opinions (Luther in Lull 2012:3 D. 1). Indicative of Disputation 1 is the pre-empting of the clear doctrines of Augustinian reasoning that echoes the same doctrinal positions of the church fathers. But, as yet, there is no clear reference to any dependence on Erasmus' text of the New Testament in Greek in 1516. ${ }^{27}$

Not only was Augustine the target of scholastic reasoning, the church fathers also suffered the same undermining (Luther in Lull 2012:3 D. 2). In other words, there was no outright refutation of patristic or Augustinian error - merely an adjustment of their theological views, seemingly as per the framed disputation, accompanied by condescension. What is absent here, is any direct reference to Scripture. Instead, Luther, in the usual scholastic tradition, formulates his theses carefully and so deals sweepingly with the scholastic interpreters. He addresses the principles which are underlying in their use and influencing their interpretation of Scripture and of the Church Fathers (Luther in Lull 2012:3 D. 3).

The formulation of these disputations follow the scholastic tradition. They are subtly formulated in thesis format, allowing just enough information to stimulate discussion. For that reason, Luther covertly juxtaposes the Early Church Fathers as opposed to more recent doctors of the church - the debate of which will expose his formulated theses. Taken together, these theses then also coalesce into narrative, illustrating the scholastic theological shift that occurred during the Middle Ages and thus revealing a new theological method. ${ }^{28}$

With the theological baseline established, it also becomes evident that Augustinian theology was being employed by Luther to show up Pelagian influences in scholastic theology. For that reason he also emphasises the underlying reason for these deviations - an inordinate emphasis on the human will. Buttressing his disputations is his reliance on Augustinian theology pertaining to grace, predestination and total depravity. Were these theological emphases a new focus formulated by Luther? Not at all. Clearly stated at the end of the 97 disputations, is Luther's conviction that what preceded

26.Disputation 1 implies that the exaggerations are "lies" (Luther in Lull 2012:3 D. 2).

27.Desiderius Erasmus (1466-1536) printed his Greek version of the New Testament alongside his Latin version of the same Testament so that scholars could assess the quality of his Latin translation.

28.Already on 18 May 1517, Luther could write 'Aristotle is continuing to fall from his throne, and his end is only a matter of time' (Currie 1908:15). the document was 'in agreement with the Catholic Church and the teachers of the church' (Luther in Lull 2012:7). As Thiselton (2015:564) suggests, while Luther saw both the strengths and weaknesses of scholasticism, it was particularly 'in its Aristotelian form, [that it] did not serve theology well'.

\section{Reasons for perverting a sound theological baseline: Disputations or theses 4-40}

\section{The will: D. 4-15}

Luther, again, follows the same pattern as above. Having established the baseline for authority, a comparative alignment of the scholastic to the theology of the Early Church and the patristics will now be possible. For that reason, in my opinion, disputation $4^{29}$ now serves as a key reference point to which one has to refer to continually in this section of theses 4-40. Luther makes it clear why.

He presents the Matthew 7:17-18 metaphor for consideration in his view of the status of a human being (Luther in Lull 2012:3 D. 4). What follows, leads to despair. As there can be no other conclusion from the disputations, in this section there can be no good tree (human being) with good fruit (works) to be found. In other words, Luther's subsequent disputations present a dismal picture in opposition to the scholastic dependence on despair. Despite the highly esteemed John Duns Scotus ${ }^{30}$ and Gabriel Biel (Luther in Lull 2012:3 D. 6; cf. footnote 2,3) there is no place for the notion that the way out for a Christian who falls short of perfection may rely on the oft-touted phrase 'facere quod in se est' [to do what is in one], expressing the supremacy of the will. Scotus's approach that, because God could do something and that it was appropriate, it could be accepted that God did it (Barth 2013:263). Such latitude was questioned by Luther - it reflected man's inclination to choose and so to propose a doctrinal stance. No scholastic reasoning can support the suggestion of merit available to make up for the shortfall between human righteousness and divine righteousness: a far cry from optimistic affirmations of any human capacity to secure assurance of salvation or to please God, for that matter.

Once this seminal idea is grasped in September 1517, Luther's continued references to the inability of the will is better understood. In fact, I suggest that this also pre-empts his later work, De Servo Arbitrio [On the Bondage of the Will] (Luther 1525). Man is not in suspension between two opposing views. Rather his inclination is to take the place and role of God (Luther in Lull 2012:4 D. 17). This dispels any ideal notion of love for God and for neighbour which Luther claims that it reveals acts of 'concupiscence against God' (Luther in Lull 2012:4 D. 22).

29.Veritas itaque est quod homo arbor mala factus non potest nisi malum velle et facere (Luther 1883:224); later translated as Es ist darum die wahrheit, das der Wen.

30.Scotus was an esteemed member of the Franciscan Order and they were obligated at the time to lecture on Luther's teachings. Assigned by the Augustinian Hermits, Luther similarly fulfilled the role of providing lectures in moral philosophy in 1508 at Wittenberg (Junghaus 2004:23). 


\section{Misdirection of the will D. 16-28}

The Scholastics used both love and hope as causes to direct the human will. Both turn out to be questionable.

\section{Love and the will}

There is no denial of the desires of human beings. Luther explores the desire to express love. Love may be directed towards God, country, the self and others (Luther in Lull 2012:4 D. 16-20, 22). Based, however, on his theological premise of the will as being corrupt and evil, not free and powerless, this claim to love must be assessed in that light. For that reason, D. 15 states that the will inclines to the 'erroneous and not to be correct precept'. For that matter, such love does not reflect true love for God, for indeed '(humans) want to be God, and do not want God to be God' (Luther in Lull 2012:4 D. 17). In fact, nothing supersedes the love of self (amor concupiscentiae) unless divine grace is antecedent to that love (Luther in Lull 2012:4 D. 20). There seems to be a reaction from Luther against Aristotelian teleology here. For Aristotle, some sense or concept of good is to be discerned in purposeful or rational human activity (praxis) which suggests a reaching towards a final or ultimate good. Luther rejects this for being an end in itself. 'Wrath and grace - therein lies the fundamental dual focus of his feeling of the world, his language, and his understanding of history' (Bayer 2004:82). Luther demonstrates in what follows the underlying idea that God alone is ultimately the desired meeting place for all human beings.

The immediate context does not make it clear if Luther is expressing this in terms of salvation. Rather it appears to refer to an interpretive understanding of grace to include the idea that to possess it, gives the individual the freedom from the bondage of sin so as to choose for God. ${ }^{31}$ To be able to do so, does not guarantee that the sinner will do so, but the action is therefore determined by the person and not by God.

A more developed scholastic interpretation of grace was to see it in terms of a commodity which may be transferred. Not so for Luther. Grace was centred in the person of God, and it is his prerogative to exercise that grace towards a sinner.

\section{Hope and the will}

If love is imperfect through its evil desire then what about hope (Luther in Lull 2012:4 D. 23)? If God is loved for his own sake as friends may experience (Luther in Lull 2012:4 D. 20, 23-26), the Aristotelian perspective of love within friendship (amor amicitiae), then it can be reasoned that this form of prevenient grace may allow for a pure love. This is contentious: How can a sinner be related in such manner of pure love to the source of love? Barth (2013:178) suggests that Luther later qualified love and hope by faith, but already here (Luther in Lull 2012:14 D. 24) we find 'For hope is not

31.Classic Arminianism improved on this scholastic notion. Until the gospel is made known, the sinner remains in bondage to sin. It is the Spirit of God who does a work of grace within the sinner's heart (e.g. Ac 16:14) and so allows for a response which of grace within the sinner's heart (e.g. Ac 16:14) and so allows for a response which
exercises the sinner's faith to believe in Christ for salvation; or, for that matter, to exercises the sinner's faith to believe in Christ for salvation; or, for that
reject the offer of salvation, denying the efficacy of the grace of God. contrary to charity, which seeks and desires only that which is of God.' In addition, Luther (in Lull 2012:4 D. 26) associates concupiscence with failure, but by extending its reach into spiritual depths so deep that despite scholastic recourse to hope, it reveals any such reliance and effort to be bankrupt. Not even a twisting of scriptural passages can be claimed in support of such views (Luther in Lull 2012:4 D. 28).

With this, Luther turned the scholastic doctrine on its head and showed its failure to affirm or achieve anything meritorious towards ultimate salvation. But he continues his argument. If the passages of D. 28 cannot substantiate anything meritorious, then how must they be understood?

\section{Eternal election and predestination of God (disputations 29-40)}

Luther now turns the spotlight on an Augustinian perspective of Scripture. What one should bear in mind is that he had just recently completed a series of lectures and sermons on the book of Romans. Although he put forward D. 29 as 'the sole disposition toward grace is the eternal election and predestination of God', it is to serve as the foundation of what is to follow. Grace was no servant of some theological method, but consequent to divine election and predestination, a bulwark against any notion of preceding grace (Van 't Spijker 2001:295).

Nothing meritorious precedes grace (Luther in Lull 2012:4 D. 30). From this premise, Luther takes the position that, notwithstanding doctrinal adjustment by the Scholastics, however reasoned, nothing can separate election from predestination (Luther in Lull 2012:5 D. 32). Indeed nothing removes any obstacles to divine grace. No scholastic teaching encouraging effort on the sinner's part, no good will, no shifting of blame claiming helplessness and no philosophical reasoning can do so effectively (Luther in Lull 2012:4 D. 33ff.). For Luther, all of these efforts resort under a single heading, viz. 'righteousness' (Luther in Lull 2012:5 D. 40). Sinners need to be made righteous.

\section{Laying the foundations of sound theology (disputations 41-53)}

\section{Remove Aristotle}

In this section Luther confronts the scholastic theologians indirectly through questioning their reliance upon Aristotle and theological interpretations that employ his principles. Aristotle's ethics 'is the worst enemy of grace' (Luther in Lull 2012:5 D. 41). Disputation 42 is a direct attack on his concept of happiness of well-being (eudaimonia) and Catholic doctrine which, for Aristotle, suggested the ultimate end of all human searching, as nothing extends beyond happiness. That is not classical Christian teaching. Nor does a blend of Christian doctrine with Aristotelian teaching allow anyone to lay claim to be a theologian regardless of the logic employed to sustain spurious teachings (Luther in Lull 2012:5 D. 43-51). To summarise Luther's opinion of Aristotelianism (in Lull 2012:5 D. 50): 'Briefly, the whole of Aristotle is to theology as darkness 
is to light. This in opposition to the scholastics.' Luther (in Lull 2012:5 D. 44) expresses his deep seated mistrust of Aristotle in a final statement 'Indeed, no one can become a theologian unless he becomes one without Aristotle.'

Not only does Luther oppose Aristotle, he also addresses scholars who favour him in their understanding and teaching of the Christian faith: scholars such as Gabriel Biel (1425?-1495), John Duns Scotus (d. 1308), Pierre d'Ailly, Cardinal of Cambrai (1350-1420), and William of Ockham (ca. 1280-1349) - all of whom were influential in developing and shaping the scholastic movement to one degree or another. ${ }^{32}$

\section{Grace and Law are not ends in themselves (disputations 54-97)}

Wannenwetsch (2004:124) cautions that Luther's understanding of the law is complex and easily misconstrued when it is seen as an idea in systemic relation to the corpus that comprises the law. For that reason, there is some caution exercised in this section so as not to extrapolate Luther's later theological insights. Luther (in Lull 2012) is, however, helpful here. He suggests that D. 54-69 displays the tensions between 'grace and law', while in D. 70-97 the tensions are between 'law and grace'. While this is an interesting scheme and merits some consideration, it must, in my opinion, be developed towards the greater point that Luther is trying to make: that of the origin of both grace and law. Once that is grasped, both grace and law are allowed to fulfil their divinely appointed roles without competition. Grace may be present (Luther in Lull 2012:6 D. 54), but not as something to be reached for; rather it is spiritually dynamic in its presence, superseding the law (Luther in Lull 2012:6 D. 58-59). Luther expresses it tersely when he says, 'it is more accurate to say that the law is destroyed by nature without the grace of God' (Luther in Lull 2012:6 D. 69). This puts paid to Ockham (Luther in Lull 2012:17 D. 56) whose latitudinal approach to grace is strongly opposed by Luther. For Luther, theologically speaking, God's grace is not all inclusive, for when justifying grace is accepted, the devastating claims of the law must be addressed. From within the ambit of grace, Luther questions the relationship between the will and the law. It is the will that strives to make every effort in good works to please God. Yet, without the law, as seen from the perspective of the love of God and the power of the Holy Spirit (Luther in Lull 2012:7 D. 84), grace and law are skewed into a twisted relationship, evident in exercises of the will. Because the will never concludes in perfection, it is sinful. Grace is not given for perfecting works, but to express the love of God. This love directs the sinner to God and to the simultaneous experience of hatred of the self (Luther in Lull 2012:7 D. 95). Luther conveys the utter dependence of the sinner on God. Not only is God's will to be sought, but also the earnest seeking after God and all that God wills (Luther in Lull 2012:7 D. 97). It is this last thesis that seems to summarise this section: the place where grace and law meet not only allows for their rightful place of origin and purpose, but places the human will in the

32.1 neither explore these influences in a particular manner, nor the changing syllogistic methodologies, preferring to keep to an overview of the 97 theses. right perspective, viz. with the desire to keep and to seek God's will.

\section{A tentative assessment}

- It seems clear that any accusation against Martin Luther or any of the prominent reformers that they did not fully understand the Scholastics, and in particular Aquinas, would be spurious. The first generation of reformers were trained in scholastic methodology and were conversant with its broad theological and philosophical sweep in the use of propositions.

- Luther believed that his critique of the Catholic Church and its teachers did not militate against the classical teachings of the church. Nor did he believe in mitigating circumstances which allowed for spurious arguments to be accepted. Tweaking or theological reorientation in any form such as a dual-layered system of belief confining theology into a sacred partition as opposed to a secular partition, was rejected.

- It must also be clear that while Luther railed against Thomas and Aristotle he sometimes did not clearly distinguish between the Thomists and the Scholastics. This probably occurred due to his over-reaching Christological perspective formulated within his own theological persuasion.

\section{Conclusion}

The final sentence of the 97 theses reveals Luther's commitment to being faithful to the classical understanding of the faith of the church. He sincerely believed that his theses did nothing but question those who deviated from the Catholic Church and its teachers (Lull 2012:3, preface). In fact, Barth (2013:402) says 'It was Luther's opinion that scholastic theology was nothing but a misjudgement of reality and an obstacle that led people astray from the statements of Sacred Scripture.' While this statement suggests Luther's engagement with scholastic methodology, it is queried whether Pettegree (2016:51) does not jump the gun when he suggests that the disputations already served as a 'manifesto of the new reform movement'. That said, it must be stated that Pettegree (2016) does not make Luther the locus of everything that contributed to the Reformation.

Some weeks later this was actually the case as Luther (in Lull 2012:8-13) challenged the Roman Church's promotion of indulgences from the view of 'the distinctive character of God's gracious action in Jesus Christ'. This threw the gauntlet down, demanding a revisit of some of the core issues comprising the gospel message, sin and forgiveness (Lull 2012:8, preface). Luther, again, resorted to the scholastic practice or formula of inviting comment and debate of his 95 theses. Six months later, in April 1518 when Luther was invited by the German Augustinian order to present his ideas to them, he did so in framing his basic theology in the form of modified but cross-centred disputations (Lull 2012:14, preface). This was presented in what is now known as the Heidelberg Disputation of 1518 (Luther in Lull 2012:14-25). 
Historically, it is foreign for the Reformed Christian theology to downplay the grace of God rationally. Present day Christian theology stresses the elevation of human happiness - often at the expense of the grace and glory of God with little time for repentance of sin and true faith in the work of Christ. Yet, it is precisely this rationalism, so clearly echoed at Worms (ratione evidente), that is under the loupe today and forces theology to reassess its assertions in the shifting milieu of present day theological practice and debate. It would be appropriate to add Luther's words in German to his Latin statement at Worms, 'Gott helfe mir, Amen'.

\section{Acknowledgements Competing interests}

The author declares that he has no financial or personal relationships which may have inappropriately influenced him in writing this article.

\section{References}

Barth, H.M., 2013, The theology of Martin Luther, a critical assessment, Fortress Press, Minneapolis, MN.

Bayer, O., 2004, 'Luther as an interpreter of Holy Scripture' in D.K. McKim (eds.), Cambridge companion to Martin Luther, pp. 73-85, Cambridge University Press, Cambridge.

Beutel, A., 2004, 'Luther's life', in D.K. McKim (ed.), Cambridge companion to Martin Luther, pp. 3-19, Cambridge University Press, Cambridge.

Currie, M.A., 1908, The letters of Martin Luther, Macmillan \& Co. Ltd., London, viewed 01 November 2017, from https://archive.org/details/lettersofmartinl00luth

Friessen, J.G., 2009, '95 theses on Herman Dooyeweerd', Philosophia Reformata 74(2), 78-104. https://doi.org/10.1163/22116117-90000465

Garcia, J.J.E., 1994, 'Individuation: The problem of individuation', in J.J.E. Gracia Jr. (ed.), Individuation in scholasticism, the later middle ages and the counterreformation, pp. 1-13, pp. 1150-1650, State University of New York Press, Albany, NY. (SUNY series in philosophy).

Hagen, K.A., 1974, A theology of testament in the young Luther: The lectures on Hebrews, ed. H.A. Oberman, E.J. Brill, Leiden. (Studies in medieval and reformation thought, vol. XII).
Hillerbrand, H.J., 1968, The protestant reformation, selected documents, Palgrave Macmillan, London.

Junghaus, H., 2004, 'Luther's Wittenberg', in D.K. McKim (eds.), Cambridge companion to Martin Luther, pp. 20-35, Cambridge University Press, Cambridge.

Loeschen, J.R., 1976, Wrestling with Martin Luther, an introduction to the study of this thought, Concordia Publishing House, St. Louis, MO.

Lull, T.F., 2004, Luther's writings in the Cambridge companion to Martin Luther, ed. D. McKim, Cambridge University Press, Cambridge.

Lull, T.F. (ed.), 2012, Martin Luther's basic theological writings, Fortress Press, Minneapolis, MN.

Luther, M., 1525, De servo arbitrio, the bondage of the will, viewed 10 July 2018, from https://www.monergism.com/thethreshold/sdg/pdf/luther_arbitrio.pdf

Luther, M., 1863, The prefaces to the early editions of Martin Luther's Bible, transl. G. Duckett, ed. T.A. Readwin, Hatchmard \& Co., London.

Luther, M., 1883, Ad subscriptas conclusions respondebit Magister Franciscus Guntherus Nordhusensis pro Biblia, Praesidente Reverando patre Martino Luthero Augustiniano, Sacrae Theologiae Vuittenberg. Decano, loco et tempore statuendis in D. Martin Luther's Werke, 1, Band, Weimar, Hermann Böhlau, pp. 224-228, in D. Martin Luther's Werke, 1, Band, Weimar, Hermann Böhlau, pp. 224-228,
viewed 08 December 2017, from https://ia800203.us.archive.org/7/items/ viewed 08 December 2017, from https://ia800203.us.
werkekritischege01luthuoft/werkekritischege01luthuoft.pdf

Marx, K. 1976, 'Karl Marx theses on Feuerbach', in F. Engles (ed.), Ludwig Feuerbach and the end of classical German philosophy, viewed 02 February 2018, https:// msuweb.montclair.edu/ furrg/gned/marxtonf45.pdf

McGrath, A., 1990, Luther's theology of the cross, Blackwell Publishing, Oxford.

Pettegree, A., 2016, Brand Luther, how an unheralded monk turned his small town into a centre of publishing, made himself the most famous man in Europe - and started the Protestant Reformation, Penguin, New York.

Potgieter, R.M., 1994, 'The sacred and the secular with special reference to Francis Schaeffer's thinking', M. dissertation, University of South Africa, Pretoria.

Reeves, R., 2015, Martin Luther and the 95 theses, viewed 02 November 2017, from https://www.youtube.com/watch?v=fJITsWCua1M

Romanoski, J.T., 2016, A handbook of scholasticism, IHM Press, New York.

Schabel, C., 2007, Theological quodlibeta in the Middle Ages: The fourteenth century, vol. 7, Koninklijke Brill NV, Leiden. (Brill's companions to the Christian tradition).

Smith, P., 1911, The life and letters of Martin Luther, John Murray, London.

Thiselton, A.C., 2015, 'Sixteenth century: 1483-1536 Martin Luther (Ninety-five theses 1517)', in A.C. Thiselton (ed.), The Thiselton companion to Christian theology, pp. 561-572, Wm B. Eerdmans Publishing company, Grand Rapids, MI.

Van 't Spijker, W., 2001, 'Early reformation and scholasticism', Nederlands archief voor kerkgeschiedenis/Duth Review of Church History, 81(3), 290-305. https://doi. org/10.1163/002820301X00031

Wannenwetsch, B., 2004, 'Luther's moral theology', in D.K. McKim (eds.), Cambridge companion to Martin Luther, pp. 120-135, Cambridge University Press, Cambridge. 